\title{
Brazilian Nonprofit Organizations and the New Legal Framework: an Institutional Perspective
}

\author{
Mário Aquino Alves* \\ E-mail address: maalves@fgvsp.br \\ Escola de Administração de Empresas de São Paulo - Fundação Getulio Vargas \\ São Paulo, SP, Brazil \\ Natália Massaco Koga \\ E-mail address: Natalia.Koga@enap.gov.br \\ ENAP \\ Brasília, DF, Brazil
}

\begin{abstract}
The purpose of this study is to understand the impact of the new Brazilian legislation regulating partnerships between the State and Civil Society (Nonprofit) Organizations between 1999 and 2002. The passing of Law No. 9790/99 - known as the Nonprofit Law - created the legal concept of Organizações da Sociedade Civil de Interesse Público - OSCIPs (Public Interest Civil Society Organizations). Based on an exploratory survey, this study, using the Institutional Theory, allowed the analysis of how older organizations (NGOs and traditional social benefit organizations) resisted to the adoption of the OSCIP standard due to organizational inertia, while acceptance of the model was greater among younger organizations, in a clear coercive and normative isomorphic development.
\end{abstract}

Key words: institutional theory; nonprofit sector; organization inertia.

Received 21 February 2006; received in revised form 30 May 2006.

Copyright (C) 2006 Brazilian Administration Review. All rights reserved, including rights for translation. Parts of this work may be quoted without prior knowledge on the condition that the source is identified.

* Corresponding author: Mário Aquino Alves

Fundação Getúlio Vargas - SP, Escola de Administração de Empresas de São Paulo, Av. Nove de Julho, 2029, Cerqueira César, 01313-902, São Paulo, SP, Brazil. 


\section{INTRODUCTION}

Between 1995 and 2001, the Federal Government decided to take the lead in a process to consolidate a new legal framework for nonprofit organizations, a requirement to allow these organizations to take part in formulating and executing public policies in a new way: partnerships between the State and Civil Society. As a result of this process, on 24 March 1999 the President of the Republic passed Law No. 9790/99 - known as the Nonprofit Law -, which established the legal concept of Public Interest Civil Organizations - OSCIPs.

Two years after the passing of Law No. 9790/99, few nonprofit organizations embraced the new standard. Contrary to what might be expected, the new coercive institutional mechanisms (Powell \& DiMaggio, 1991) - that provided access to new resources by means of specific Letters of Partnership with OSCIPs - were unable to trigger the expected adhesion. Faced with the possibility that the law might not catch, the government took steps to make the legislation more attractive to nonprofit organizations, passing Provisional Measures (Medidas Provisórias) No. 2143-33, dated 31 May 2001 and No. 2113-32, dated 21 June 2001. In practice, these provisional measures brought the new legislation closer to the old one, which made the legal change practically innocuous.

The purpose of this article is to understand - from the perspective of Institutional Theory - the changes brought about by the new legislation governing partnership relationships between the State and Civil Society (Nonprofit) organizations, based on the low adhesion to the model between 1999 and 2002.

This study proceeds as follows. It first presents a bibliographical review of the institutional approach to organizations. Then, it discusses the context that led to the passing of Law No. 9790/99 and compares this law to its predecessor. Subsequently, it explains how the survey on the alignment of Brazilian nonprofit organizations as OSCIPs until March 25th, 2002 took place, so as to enable understanding its distinctive traits. Finally, based on the results obtained, it considers the institutional issues that caused resistance to the OSCIP model and, consequently, to the change in the law.

\section{INSTITUTIONAL THEORY AND RESISTANCE TO CHANGE}

There is increasing acceptance of the Institutional Theory in the field of Brazilian organizational studies (Caldas \& Vasconcelos, 2002; Carvalho, 1999; Carvalho, Vieira, \& Lopes, 1999; Machado-daSilva, 2001; Pacheco, 2001; Vieira \& Misoczky, 2000), in a development that might even be regarded as the institutionalization of the neo-institutional theory itself (Tolbert \& Zucker, 1996). This process of assimilating the institutional theory arises, evidently, from the vast possibilities it offers towards understanding how organizations are submitted to institutional pressures from the environment as regards legitimation and, consequently, survival (Powell \& DiMaggio, 1991).

Institutional theory is not, however, a monolithic theoretical body. Quite the opposite, it is hard to set it into a single frame of reference, as it is a theoretical effort made by many authors at different times. Although there is a strong current setting the new institutionalism from the old (Powell \& DiMaggio, 1991), this article leaves this separation aside as, were it maintained, it might inhibit the analytical potentials of this approach (Selznick, 1996).

Institutional theory argues that organizations adapt to the environment moved not by issues of efficiency, but by the need for legitimacy. This perspective challenges the notion of organizations as being rational and objectives-driven, introducing a portrait of organizations guided by myths, symbols, and a necessity for social legitimacy (Powell \& DiMaggio, 1991). 


\section{Isomorphic Processes and Organizational Change}

Organizations operating in the same area are often very similar, whether in form or in practice. Powell \& DiMaggio (1991) defined this phenomenon as institutional, outlining three institutional isomorphism mechanisms: coercive, mimetic, and normative.

Coercive isomorphism "is the result of formal and informal pressures exerted on organizations by other organizations - on which they depend - and by cultural expectations of the societies in which they operate" (Powell \& DiMaggio, 1991, p. 67). These pressures materialize as actions of force or persuasion or as invitations to take part in coalitions or associations. Cases of coercive isomorphism are, for example, organizational changes caused by governmental pressures, usually based on legislation. The legal environment affects many aspects of an organization's behavior and culture.

Mimetic isomorphism occurs where an organization emulates another's practices to face environmental uncertainties. "When organizational technologies are little understood [...]; when objectives are ambiguous; or when the environmental creates symbolic uncertainty, organizations can model after other organizations” (Powell \& DiMaggio, 1991, p. 69). Organizations end up replicating those other organizations regarded as more legitimate or more successful.

The third source of isomorphism is normative. Normative isomorphism is usually grounded on professionalization processes. "By professionalization we understand collective struggle of members of an occupation, to define the conditions and methods of their work, and to establish a cognitive base and legitimation for their occupational autonomy” (Powell \& DiMaggio, 1991, p. 70).

All types of organizational change brought about by isomorphic processes occur as ways to facilitate the work of organizations in several activities: transactions with other organizations; professionals recruiting; recognition as legitimate, respectable organizations; and alignment that lets them take part in public and private competitions. These activities must, therefore, appear legitimate in the organizational field.

\section{The Legitimation of New Practices}

A new set of practices is neither legitimate nor illegitimate in and of itself. It is first invented or adopted by a small group of organizations interested in solving a technical problem (Tolbert \& Zucker, 1999). Therefore, institutionalization takes place in stages, as discussed below.

Firstly, practices are undergoing sufficient formalization to enable transmission to other organizations or new members of an organization (Zucker, 1991). Adoption of such practices can be anticipated at an early stage if the practices have characteristics that make rationally them viable (March \& Simon, 1958), i.e., if they include technical, political, cultural and economic dimensions.

At a second stage, the actors responsible for the decision-making process at organizations start believing, that the new practices are valid and, based on this, an increasing number of organizations begin to adopt the new practices. Adopting organizations can ascribe values to the new practices, based on what the may have learned about them from other actors - known as the champions of innovation (Tolbert \& Zucker, 1999) - in the field (competitors, consultants, media, etc.). Moreover, the higher the number of organizations adopting these new practices, the more knowledge that is apprehended and disseminated in the field, which reduces the cost of adoption by other organizations (Tolbert \& Zucker, 1999).

A team of institutional entrepreneurs - champions - with material interest in the dissemination process (Abrahamson, 1996; Caldas \& Wood, 1999) creates a field for innovation. These champions may be professional groups, organizational gurus, special interest groups or consultants, who head the institutionalization process because institutionalization facilitates the action of champions (Tolbert \& Zucker, 1999). In order to create such a field, they need to connect a set of meanings that can be applied more generally to the practices and to the universe of adopting organizations (Strang \& Meyer, 
1993). Champions must simultaneously define a problem to be solved and the practices to solve it. When linked to classes that are regarded as legitimate, the practices acquire normative legitimacy (Tolbert \& Zucker, 1999). If the field in which they are embedded is soundly established, and where there are meaning that can be immediately assigned to the new practices, they will be quickly institutionalized.

\section{Organizational Inertia and Resistance to Change}

The environments in which organizations operate often cause impacts of several natures that give organizations the possibility of change. But not all of them change and some of those that do change do so very slowly. This process is known as organizational inertia. This is understood to mean the process by which organizations change slowly and through undesired processes (Stinchcombe, 1965).

Although (structural) inertia is a topic more closely associated with the Population Ecology authors like Hannan and Freeman (1984), earlier institutional authors already approached the issue.

Selznick (1949), on studying the establishment of the Tennessee Vallley Authory (TVA) and the implementation of its grassroots development policy, showed that organizational leaderships tend to react to changes in organizational character. Organizations themselves become institutions when they are imbued with values, being raised from simple instruments to sources of personal gratification and group integrity. This process leads to a different organizational identity: character (Selznick, 1984). The study of the formation of organizational character is, therefore, the institutional analysis process itself. "The emergence of organizational character reflects the irreversible element in experience and choice [...] acceptance of the irreversible practices is the process by which an organization's character is formed" (Selznick, 1984, p. 35). An organization's institutionalization process reflects its own history, the histories of those who worked there, the several vested interests of the groups it comprehends, and the manner how it adapted to its environment (Selznick, 1984). On the other hand, if institutionalization is not a straightjacket, that keeps the organization inert, “... management changes are often difficult when individuals have become used to and identify with longstanding procedures [...] there is resistance against any change that may jeopardize individual interests" (Selznick, 1984, p. 15). Therefore, organizational inertia arises when these vested interests are threatened.

Arthur Stinchcombe (1965), for whom inertia may arise in the process of an organization's stabilization, followed a similar path. An organization's format remains relatively stable over time because it was the most effective at the time of the establishment of the organization, "and because it tends to become institutionalized even in if environmental pressures indicate that it is no longer as effective as before" (Stinchcombe, 1965, p. 153). Stinchcombe (1965) analyzed the reasons that lead organizations to maintain a stable organizational structure, listing three basic ones: the force of tradition, the presence of interests of certain groups who attempt to retain their positions and certain operational ideologies that wish to keep what has always worked (Stinchcombe, 1965). Here, too, the issue centers on vested interests: the organization resists change even when these are threatened.

If both Selznick and Stinchcombe attribute organizational inertia to vested interests, Powell and DiMaggio (1991) and Meyer and Rowan (1977) argue that inertia is seated on the relationship between stability and legitimacy in the organizational field - where institutions are -, and on the strength of common understandings that, while seldom made explicit, result from institutional imperatives. An organization can only remain stable if its practices are regarded as legitimate by the field in which they exist.

There is yet another, and peculiar, means by which organizations remain inert: cerimonialism (Meyer \& Rowan, 1977). According to these authors, if the form of acting of the technical core of an organization is restricted by implications concerning efficiency, the management might decouple from other outside agents, creating mechanisms that simulate - by means of ceremony - the adoption of processes regarded as legitimate in an organizational field in order to deal with environmental pressures. As a result of this decoupling process, their legitimacy before other actors will increase, as 
will the possibility to consequently secure resources to pursue activities. A company, for example, might adopt the legal appearance of a nonprofit organization, but continue to operate as a private firm might, distributing profits to partners under the guise of compensation for services provided.

\section{The BraZilian NonProfit SeCtor's NeW Legal FramewOrK}

Since the early 1990s, when the idea of Nonprofit Sector started to be incorporated into the several debate forums concerning the role of Civil Society in Brazil's social context, another debate in parallel took place regarding the need to create a new legal framework to replace the legislation then in force which, because it contained concepts created in the early 1930s, was no longer appropriate to the new reality of relationships between the State and Civil Society (Comunidade Solidaria, 1997).

In 1997, the Board of Comunidade Solidaria - a quango (quasi-non-governmental organization) that represented the governmental interface for Civil Society - began the Political Debate process with the participation of several representatives from Civil Society organizations and the government to restructure the nonprofit sector's legal framework (Ferrarezi, 2001). At the sixth round of political debate, the following general agreements were established:

1. The Nonprofit's Strategic Role. Strengthening the Nonprofit Sector, made up of public, nonprofit Civil Society entities, would be a national strategic decision due to its ability to generate projects, take responsibilities, take initiatives and mobilize the resources needed for the country's social development.

2. The Change in the Nonprofit Sector's Legal Framework. Strengthening the Nonprofit Sector required reformulating its legal framework.

3. Comprehensiveness of the Nonprofit Sector. Reformulating the Nonprofit Sector's Legal Framework required building a broader understanding of what the very concept of Nonprofit Sector comprehended.

4. Transparency and Responsibility in the Nonprofit Sector. Expanding and strengthening the Nonprofit Sector would befall, above all, Society itself, which should establish transparency and accountability mechanism capable of leading to self-regulation.

5. The State and the Nonprofit Sector. Reformulating the Nonprofit Sector's Legal Framework required that in addition to rights, Nonprofit Sector entities' responsibilities before the State be established, wherever State resources are involved.

The same meeting led to the establishment of specific agreements concerning: administrative records and files; agreements and covenants; self-regulation mechanisms; institutional answerability mechanisms; donations (and the pursuit of a new funding model); volunteer work regulation; closedend labor contracts; and information (Comunidade Solidaria, 1997).

\section{The Characteristics of Law No. 9790/99}

Law No. 9790/99 was passed in March 1999 to simplify procedures for institutional recognition of entities as Public Interest Civil Society Organizations (Organizações da Sociedade Civil de Interesse Público), as well as to facilitate partnerships with the public power, by means of criteria that were more closely related with the verification of the organization's effectiveness and efficiency.

For the purpose of the new law, nonprofit organizations were deemed to be private legal entities that did not distribute net or gross operating surpluses, dividends, bonuses, or shares in its assets acquired in the pursuit of activities among its partners, associates, directors, officers, employees or donors, 
using them entirely to attain their corporate purpose. Many organizations would therefore benefit from the law, as their corporate purpose did not include any activity previously considered as public utility. Only welfare organizations (Law No. 91, dated Aug, 28, 1935), in their many forms, received this title. Law No. 9790/99, expanding the realm of public interest, also extended the OSCIP classification to entities whose corporate purposes included conservation, study, environmental and cultural research, microcredit, legal assistance, and others.

To foster partnerships with OSCIPs, Law No. 9790/90 established the figure of Letter of Partnership. Unlike covenants and agreements, Letters of Partnership were proposed as more transparent and democratic instruments to encourage nonprofit organizations' activities and projects.

What was intended was for this law to slowly replace Law No. 91, dated 28 August 1935, which created the legal concept of Public Utility Titles (Títulos de Utilidade Pública), regulated by Decree No. 50517, dated 02 May 1961. This earlier law was not revoked. Law No. 9790/99 set forth an initial period of two years for nonprofits that already had Public Utility Titles to requalify as OSCIPs (as long as they met the legal requirements), and assuring them simultaneous maintenance of these two titles for the period (until 23 March 2001).

\section{The Resistance to the OSCIPs ACT and the Changes it Made}

Although the political discussion rounds Comunidade Solidária promoted did achieve six general agreements (Comunidade Solidaria, 1997), there was little initial acceptance of Law No. 9790/99. Close to the end of the two-year period established by law, contrary to governmental expectations, the number of requests for requalification as OSCIP submitted to the Ministry of Justice was very low. As indicated in Table 1, in the first two years (1999 e 2000), only 445 requests were submitted and, out of these, a mere 91 were granted (20.45\%). This is a low figure, even for a sector whose statistics have not been subject to actual updates since 1991 (Landim, 1993). That year, the survey made by ISER researchers for the worldwide nonprofit mapping project promoted by the Johns Hopkins University, there were around 219,000 nonprofit organizations in Brazil (Landim, 1993).

Table 1: Requests for Requalification as OSCIP (1999-2001)

\begin{tabular}{|l|l|l|l|l|}
\hline Year & $\mathbf{1 9 9 9}$ & $\mathbf{2 0 0 0}$ & $\mathbf{2 0 0 1}$ & Total \\
\hline Granted & 8 & 83 & 252 & 343 \\
\hline Rejected & 123 & 231 & 110 & 464 \\
\hline Total & $\mathbf{1 3 1}$ & $\mathbf{3 1 4}$ & $\mathbf{3 2 6}$ & $\mathbf{8 0 7}$ \\
\hline
\end{tabular}

Source : Ministry of Justice (2002).

This shows that despite an apparent consensus in the Brazilian nonprofit sector discourse, there was substantial resistance by nonprofit organizations. The first portion of the survey identified two groups of resistance to the new law: NGOs and traditional philanthropic associations. These groups are responsible for the main criticisms against Law 9790/99.

A little before the two-year period established by law ended, Provisional Measure (Medida Provisória) No. 2143-33, dated 21 May 2001, extended the original period for an additional three years, providing a total of five years for entities that held simultaneous Public Utility and OSCIP Titles to choose between them (until 23 March 2004).

Provisional Measure No. 2113/32, dated 21 June 2001 amended law No. 9245/95, which thereafter also comprehended OSCIP-qualified entities. Since then, OSCIPs can offer Income Tax-deductible receipts to donating Legal Entities (corporate donations are an important source of financial support 
for entities). Except for the Income Tax exemption extended to all nonprofit organizations that meet the requirements set forth in article 15, Law No. 9532/97, OSCIPs had access to no tax incentives.

As can be seen in Table 1, the number of submission in 2001 was practically the same as in 2000 . What rose was the number of granted requests which rose from $20.45 \%$, in the first two years to 77.3\% in 2001. This fact must be taken with a grain of salt: the figures do not new requests from repeat submissions. While there was an increase to the number of granted requests, this may reflect in part repeat submissions, rather than new ones; the total number of OSCIP-qualified organizations is still small. In addition, the government was forced to retreat and extend deadlines and benefits, clear admission that the law was not enjoying success.

\section{ON THE RESEARCH}

After this brief theoretical review of the institutional theory, emphasizing the manners in which it indicates mechanisms that explain change and resistance to change as a result of inertia, and of the new legal framework for the nonprofit sector, we proceed to present the research that illustrates the considerations made in this article. This study was prepared based on a broader survey whose purpose is to explore possible changes caused in the universe of Brazilian Nonprofit organizations, after the passing of Law No. 9790/99, in March 1999. This law, known as the Nonprofit Act, created a new legal concept: Public Interest Civil Organizations (Organizações da Sociedade Civil Interesse Público - OSCIP). The Fernando Henrique Cardoso administration expected massive adhesion to the new model within a short period of two years. This survey was carried out to determine whether or not such adhesion took place.

The first step was to seek preliminary information on OSCIPs from the Ministry of Justice, the body in charge of analyzing and granting qualification requests. Since, as discussed earlier, adhesion was low in the first two years, open, semi-structured interviews were scheduled with relevant persons in the Brazilian Nonprofit scenario to identify points of interest so that the research might proceed.

The second step was to identify the organizations whose requests for OSCIP qualification were granted by the Ministry of Justice, pursuant to the law. At the Ministry's Website, we obtained the organizations' postal information, date of qualification and area of operation.

For the purposes of this survey, the 415 earliest OSCIPs created in Brazil were selected, i.e., those that were qualified in the period from 24 March 1999 - the effective date of law No. 9790/99 - until 25 March 2002 - the latest update of the Ministry of Justice's website at the time of the establishment of the objective of the survey. Between May and July 2002, questionnaires were sent to these 415 OSCIPs to identify their main characteristics: date of establishment; data of OSCIP qualification; purpose of the institution; the institution's action history; main beneficiaries; number of beneficiaries and number of collaborators; operating area, scope and region; and funding sources.

Of the 415 questionnaires mailed, 124 were answered and returned between July and December 2002. This response rate (close to 30\%) can be considered high, as this is a non-mandatory questionnaire, i.e., one in which respondent participation takes place spontaneously. For the purposes of this study, only the data and information relative to the specific topic are presented throughout the analysis. Other information will be the subject of future projects. 


\section{SURVEY RESULTS}

Prior to describing the results obtained from the analysis of the data contained in the 124 returned questionnaires, we provide a brief description of the information provided by the Ministry of Justice concerning the universe of 415 OSCIPs initially selected.

The Ministry of Justice data show that greater adhesion to the OSCIP model takes place after mid2001, more than two years after Law No. 9790/99 came into force, as shown in Chart 1 . One interesting fact stands out regarding the coincidence between the period in which this greater adhesion to the model takes place and the enactment of two significant amendments to the law. These changes occurred as a result of two Provisional Measures (Medidas Provisórias): MP No. 2143-33, dated 31 May 2001, and MP No. 2.113-32, dated 21 June 2001, which granted, respectively, an extension to the period during which the OSCIP title might be maintained simultaneously with another that the organization had previously, and the status of beneficiaries of Income Tax-deductible donations. Note that $65 \%$ of the organizations qualified after May 2002, i.e., after the changes to the law began.

\section{Chart 1: OSCIP-Qualified Organizations by Date}

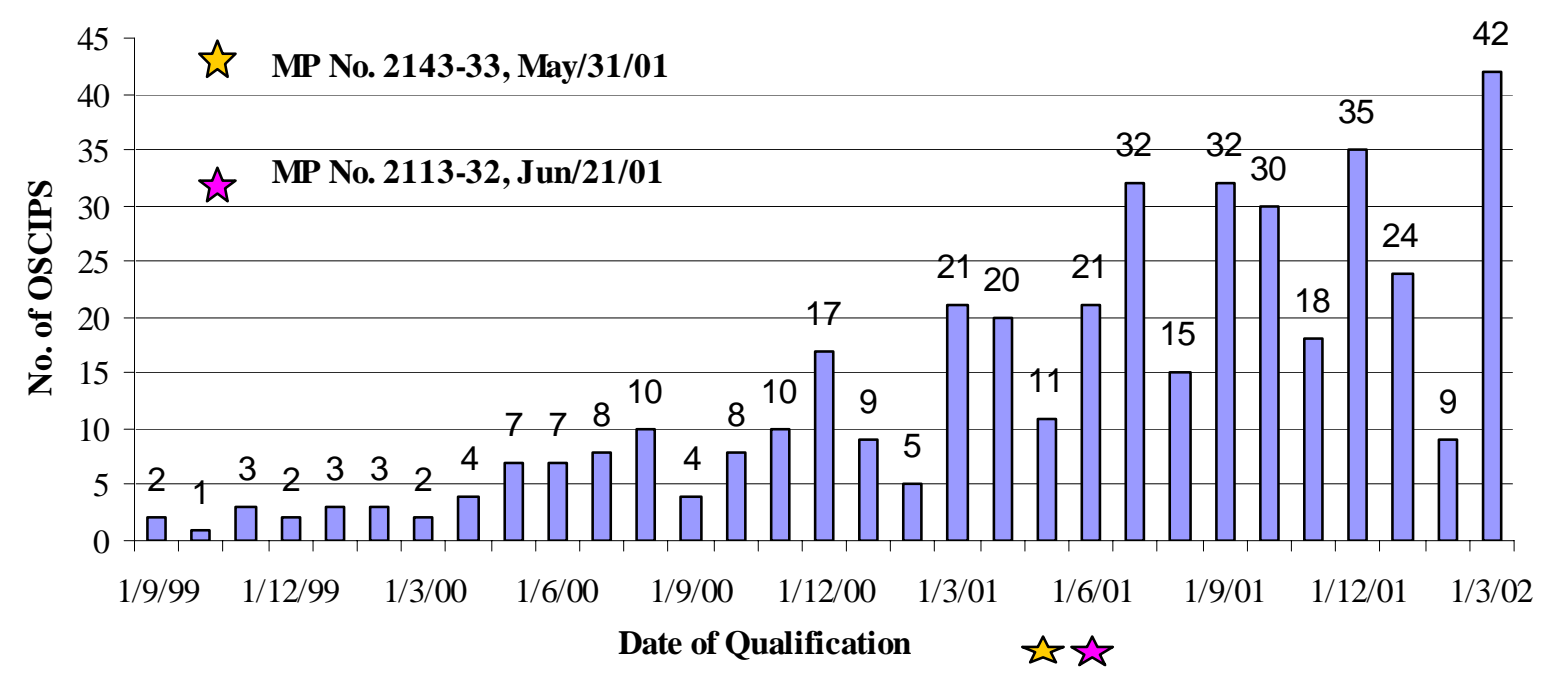

Source: Ministry of Justice (2002).

The sample, as shown in Table 2, displays the same behavior observed in the analysis of the general universe of 415 OSCIPs. Sixty-five percent of the 124 OSCIPs qualified after May 2001 (data in red) close to the 62\% out of 415 OSCIPs qualified after May 2001. 
Table 2: OSCIP-Qualified Organizations by Date of Qualification

\begin{tabular}{|c|c|c|c|c|c|c|c|}
\hline Date & Org. & Date & Org. & Date & Org. & Date & Org. \\
\hline Sep/02/99 & 1 & Sep/29/00 & 1 & Apr/03/01 & 3 & Sep/21/01 & 3 \\
\hline Sep/22/99 & 1 & Oct/23/00 & 2 & Apr/17/01 & 1 & Oct/08/01 & 3 \\
\hline Jan/13/00 & 1 & Nov/06/00 & 2 & Apr/24/01 & 2 & Oct/18/01 & 3 \\
\hline Feb/02/00 & 1 & Nov/16/00 & 1 & May/04/01 & 2 & Oct/31/01 & 2 \\
\hline Mar/22/00 & 1 & Nov/22/00 & 3 & May/24/01 & 2 & Nov/12/01 & 2 \\
\hline Apr/03/00 & 2 & Dec/20/00 & 2 & Jun/06/01 & 1 & Dec/10/01 & 7 \\
\hline May/09/00 & 1 & Dec/29/00 & 2 & Jun/26/01 & 2 & Dec/14/01 & 2 \\
\hline May/26/00 & 1 & Jan/16/01 & 2 & Jul/13/01 & 3 & Dec/27/01 & 3 \\
\hline Jun/06/00 & 1 & Feb/22/01 & 3 & Jul/24/01 & 10 & Jan/17/02 & 5 \\
\hline Jun/26/00 & 4 & Mar/01/01 & 3 & Aug/10/01 & 1 & Feb/07/02 & 2 \\
\hline Jul/05/00 & 1 & Mar/13/01 & 1 & Aug/23/01 & 2 & Mar/07/02 & 6 \\
\hline Aug/22/00 & 3 & Mar/22/01 & 1 & Sep/12/01 & 7 & Mat/25/02 & 9 \\
\hline
\end{tabular}

Source: the present survey.

As for the date of establishment of these organizations, some interesting aspects can be inferred. Out of the 124 organizations, 122 indicated their dates of establishment. According to Table 3, the overwhelming majority of the organizations that attempted OSCIP qualification (86\%) were founded in or after 1991.

Table 3: OSCIP-Qualified Organizations by Date of Establishment

\begin{tabular}{|c|c|c|c|c|c|c|c|c|c|c|c|c|c|}
\hline $\begin{array}{c}\text { Until } \\
1990\end{array}$ & 1991 & 1992 & 1993 & 1994 & 1995 & 1996 & 1997 & 1998 & 1999 & 2000 & 2001 & 2002 & Total \\
\hline 17 & 3 & 5 & 3 & 4 & 4 & 4 & 8 & 10 & 13 & 28 & 22 & 1 & 122 \\
\hline $14 \%$ & $2 \%$ & $4 \%$ & $2 \%$ & $3 \%$ & $3 \%$ & $3 \%$ & $7 \%$ & $8 \%$ & $11 \%$ & $23 \%$ & $18 \%$ & $1 \%$ & $100 \%$ \\
\hline
\end{tabular}

Source: the present survey.

One may infer from the table that the two most important segments in the so-called Brazilian Nonprofit Sector (Fernandes, 1994), traditional welfare and non-governmental organizations (created in the 1970s and 1980s to support social movements), which make up the majority and most visible portion of this sector, practically remained as they were, i.e., in institutional terms, organizations in these segments adopted an organizational inertia strategy. Another important datum from this table: $53 \%$ of the organizations were founded in or after 1999, suggesting that they may have been established with the single purpose of seeking possible funds by means of establishing Letters of Partnership with the public power.

To identify the researched institutions' funding sources, a field with nine non-exclusive options, one of which was other sources. 
Table 4: Sources of Funding of the OSCIPs that Answered the Questionnaire

\begin{tabular}{|l|c|c|c|}
\hline Source & Answers & \% of answers & \% of OSCIPs \\
\hline Businesses, Foundations and Business & 45 & $14 \%$ & $36 \%$ \\
\hline Institutes & 44 & $14 \%$ & $35 \%$ \\
\hline Federal government body & 40 & $13 \%$ & $32 \%$ \\
\hline Local government body & 38 & $12 \%$ & $31 \%$ \\
\hline Member contributions & 35 & $11 \%$ & $28 \%$ \\
\hline Sales of products and services & 26 & $8 \%$ & $21 \%$ \\
\hline International cooperation agencies & 21 & $7 \%$ & $17 \%$ \\
\hline Multilateral and bilateral agencies & 6 & $2 \%$ & $5 \%$ \\
\hline Other sources & 50 & $16 \%$ & $40 \%$ \\
\hline Non-funded & 2 & $1 \%$ & $2 \%$ \\
\hline Did not know or did not respond & 4 & $1 \%$ & $3 \%$ \\
\hline Disqualified & 1 & $0 \%$ & $1 \%$ \\
\hline Total & 312 & $100 \%$ & \\
\hline
\end{tabular}

Source: the present survey.

Based on the data from Table 4, other sources has the greatest presence: this option was checked in $40 \%$ of the returned questionnaires. Some of these specified what these other sources of funding might be. In some cases, the source mentioned could have fit into other choices available in the questionnaire, such as in the case where other sources are member donations, which might have been included under member contributions. We decided, however, to maintain the original responses in order to preserve the respondent's understanding. At another part of these questionnaires, other sources of funding that the questionnaire did not address were presented, such as the Church and other Nonprofit organizations and donations from non-member individuals.

The heavier presence of private funding (40\%) in Table 4 as compared to the several governmental sources of funding draws attention, but only in relative terms. Considering the fact that the federal, local and state governments are present in 35\%, 32\% and 28\% of responses, respectively, the relevance of public funding for the sampled organizations' activities is clearly depicted.

Another interesting datum drawn from the questionnaires is the number of options checked by organizations, as can be seen in Table 5. Although most of them indicated up to three different sources of funding, $6 \%$ of the 117 respondents checked more than six sources, which might raise the question of whether this is a kind of behavior according to which the main motivation for the organization is pursuit of as many public sources of funds as possible, as if they were rent collectors (Monzoni Neto, 2001). 
Table 5: Number of Funding Source Options Checked

\begin{tabular}{|c|c|c|c|c|c|c|c|c|c|}
\hline Sources Options & 1 & 2 & 3 & 4 & 5 & 6 & 7 & 8 & 9 \\
\hline Number of Responses & 32 & 31 & 30 & 13 & 5 & 3 & 2 & 1 & 0 \\
\hline
\end{tabular}

Source: the present survey.

\section{Analysis Of The DATA In The Light Of Institutional TheORY}

The context of the reform of the Nonprofit Sector's legal framework in Brazil and, specially, the data obtained in this survey, suggest some interesting evidence to demonstrate, in the light of the institutional theory, the reason for the initial ineffectiveness of Law No. 9790/99 as regards adhesion by part of Brazil's nonprofit organizations.

\section{Organizational Resistance and Inertia among NGOs and Traditional Organizations}

As shown earlier by the data relative to the date of founding of the qualified organizations, there is evident resistance to the new law on the part of the main actors in the possible field of the Nonprofit: NGOs and traditional entities. And this resistance is demonstrated quite simply by an organizational inertia process.

More than a simple matter of unawareness of the law or even red-tape related problems, the Law 9790/99, also known as the Nonprofit Act, is still ineffective because it has not achieved legitimacy in the field. In this case, the new model's lack of legitimacy is grounded on two factors: the resistance from actors in the field and the maintenance of the previous organizational model.

Resistance from NGOs. Since the beginning of the Fernando Henrique Cardoso (1995-2001) administration, there was an attempt to draw the government and NGOs closer by means of Comunidade Solidária. NGOs - represented by ABONG (Brazilian Nongovernmental Organizations Association) - answered to this overture at first. They were offered an invitation to have a representative take a seat in the Board of Comunidade Solidária. This invitation was accepted with the appointment of Jorge Durão from the NGO FASE, as ABONG representative.

This movement soon lost momentum, due mostly to the government's lack of dedication in advancing and funding solutions for the social area (Bava, 2001). In May 1996, the ABONG representative renounced from the Board of Comunidade Solidária as protest against the government's actions in the social field.

After this estrangement, ABONG took a more cautious stance as regards the government's attempts. When invited to take part in the Political Discussion debates concerning the new legal framework for the Nonprofit, ABONG accepted because it understood this to be a public space where its proposals and ideas might be heard (Bava, 2001). According to Sílvio Caccia Bava, a former chairman of the Brazilian NGO Association (ABONG), after several rounds of Political Discussion, a project was drawn but, when the Bill was passed and became the Act, a surprise was in store: "the discussions did not correspond to the final text of the Law 9790/99" (Bava, 2001). Therefore, the NGOs remained bound to vested interests, i.e., they maintained a character of ideological opposition to the government and its ideologies.

Maintenance of the previous status. Traditional welfares, in turn, are those professional or religious institutions whose purpose is charity. They are the most numerous and the oldest in the Brazilian nonprofit universe (Landim, 1993). Usually, they perform one single specific activity (hospitals, day- 
care centers, homes, etc.) and declare themselves apolitical, meaning without any kind of political commitment.

The major welfare organizations took the brunt of the effects of the discourse for professionalization of the Nonprofit Sector (Alves, 2002; Carvalho, 1999) and even attempted to update, particularly in the management area. In addition, many organizations felt a need to associate themselves with others for defense against outside threats (tax legislation and the issue of pilantropia - a popular term to describe fraudulent schemes disguised as welfares).

This is the context in which Rede Brasileira de Entidades Filantrópicas (Brazilian Philanthropic Entities Alliance) - REBRAF (2001) appears, playing for the welfares the same role ABONG plays for NGOs. Given that this is a ploy by organizations that never articulated in the defense of their interests, their even forming an organization such as REBRAF is surprising.

The establishment of REBRAF was brought about by Federal Law No. 9732/98, which eliminated tax exemptions for all welfares suspected of fraud (REBRAF, 2001).

Unlike ABONG, REBRAF did not oppose the government, so much so that REBRAF had no official stance on the OSCIPs Law. Therefore, for more traditional organizations, the main problem raised by the OSCIPs Law was the lack of tax incentives since, besides Income Tax exemption (and that only for entities who do not pay salaries to their managers), OSCIPs benefited from no other incentives. In comparison, entities that already enjoyed Federal Public Utility Titles could offer Income Tax-deductible receipts to donating legal entities. Law No. 9249/95 establishes that donations made to Public Utility Civil Entities can be deducted for Income Tax purposes up to a limit of 2\% of net profits. OSCIP qualification offered no similar benefits.

If these organizations already complied with a certain legal status, a change in law that allows them to retain that status, even if not ideal, is a better choice than risking a new, uncertain model. In this sense, their position is similar to that of the NGOs: "why should NGOs adopt a model that carries so many doubts with it (...) if the law allows it, it is better to stick to the old model”. (Bava, 2001).

Regarding this point, it is worth noting that the law allows organizations to - simultaneously - keep their Public Utility Titles and obtain OSCIP certification (even though only until 2005). This would allow traditional organizations and even some NGOs to trigger a decoupling process (Meyer \& Rowan, 1977): while meeting the new institutional environment by means of their OSCIP certifications, they would also retain their earlier structures, which would not challenge the organization's character and would meet its vested interests (Selznick, 1984). But acceptance of the model was so low that not even this decoupling strategy was possible. This may be the result of a lack of incentives. As noted by Silvio Caccia Bava, the OSCIP status might only offer some advantages to NGOs through the ability to enter into Letters of Partnership. Since few such partnerships were formed, NGOs preferred to wait and see whether the OSCIP model would catch or not (Bava, 2001). And even if there were more Letter of Partnership, there would still be the issues of legitimacy and overcoming the discourse, which are relevant obstacles for many NGOs. Welfare organizations are of the veiled opinion that the project can be more of a curse than a blessing. This is because the new law offers no advantages to entities that already have Public Utility Titles; even the ability to pay salaries to managers fails to attract them because they would have to give up fiscal benefits when both titles could no longer be maintained at once.

Finally, another explanation to the fact that welfares, in particular, retained their earlier status lies in their essential characteristic: tradition (Milofsky, 1997). By tradition we mean “(...) another manner of referral to practices and benefits achieved whose effects are felt over long periods of time" (Milofsky, 1997, p. 263). Faced with signs of environmental change, these organizations prefer to maintain their structures, even if the environment points towards more legitimate formats (Stinchcombe, 1965). This does not apply, however, to younger organizations such as NGOs, where the burden of tradition is lighter that that of their underlying values. 


\section{Isomorphism and Legitimacy in New Nonprofit Organizations}

The case of Law No. 9760/99 might be interpreted, in classical terms, as pressures the government exerts through legislation which, by force of law, would lead to a coercive isomorphism process (DiMaggio \& Powell, 1991) among nonprofit organizations, who would comply, en masse, with the OSCIP model to be able to enter into Letters of Partnership with the state, leveraging funding. But the expected migration of organizations towards the OSCIP status as defined by Law No. 9760/99 did not come to be. The law's attractions - such as the ability to pay salaries to managers and to enter into Letters of Partnership - were not sufficiently strong to lead older nonprofit organizations to adopt the OSCIP model. Still, both coercive and normative isomorphism can be identified in the case at hand.

Although slight in comparison to the sector as a whole, the number of new organizations submitting requests for OSCIP qualification is quite expressive as compared to the total, as shown in Table 3. New organizations need quick legitimacy in the field to ensure access to funds and, consequently, to take root and survive. Since they have not yet become institutionalized (Selznick, 1984), the lack the required legitimacy in the field. Therefore, the law provides legitimacy - as in the processes of adopting ISO 9000 norms (Caldas \& Vasconcelos, 2002) - more quickly than the natural passage of time, not to mention the immediate ability to enter into Letters of Partnership with the government.

There is a professionalization process, as yet incipient, under way in the Nonprofit, mainly with the training of specialized professionals, such as managers, attorneys and, mostly, fund raisers, people who specialize in raising funds for nonprofit organizations. There is even a Brazilian Fund Raisers' Association (Associação Brasileira de Captadores de Recursos - ABCR), which as established an ethics code for the activity (ABCR, 2001).

These professionals, in order to acquire legitimacy in the field, among other factors, have been acting as champions for the sector (Tolbert \& Zucker, 1999), in the sense of disseminating the ideology of necessary professionalism among nonprofit organizations in Brazil. By acting professionally at these organizations - particularly younger ones -, whether as hired professionals or as consultants, they become responsible for disseminating the OSCIP model as the one best aligned with the proper operation of organizations, causing an incipient normative isomorphism movement in the field of nonprofit organizations.

\section{FinAL CONSIDERATIONS}

When Law No. 9790/99 was sanctioned by President Fernando Henrique Cardoso in March 1999, Brazilian Civil Society organizations, identified as the Nonprofit, were expected to quickly and expressively adopt the OSCIP model.

However, as discussed earlier, the massive, quick adhesion the government expected never took place. In this sense, the government forced itself to amend the law - extending terms and making donations Income Tax-deductible. On analyzing these changes, one concludes that they draw the OSCIP model closer to the old Public Utility Title, inasmuch as they grant benefits that were exclusive to the latter and ensure simultaneous maintenance of the two titles for a period of five years, i.e., three more than originally intended by Law No. 9790/99.

The Institutional Theory - vis-à-vis the analysis of the data from the exploratory survey - lets us analyze how older organizations (NGOs and traditional welfare organizations) resisted against OSCIP qualification as a result of organizational inertia, as well as how coercive and normative isomorphic pressures have had a stronger impact on younger organizations.

The spirit of Law No. 9790/99 is embedded in the new Nonprofit Sector discourse. Embracing this discourse, the government, through Comunidade Solidaria, proposed a model for nonprofit 
organizations that restricts them to predetermined scopes which, in turn, fail to take the sector's diversity into consideration. Even the existence of a Nonprofit Sector is open to argument (Spink, 2000).

The reality is complex enough to show that there is a field of nonprofit organizations - which, as a form of social construction, may be called the Nonprofit. Organizational fields (Scott \& Meyer, 1991), as noted by Misoczky (2001), based on Pierre Bourdieu's work, are not neutral complexes in which institutions simply appear and lend legitimacy to those that observe them. Organizational fields are power fields (Bourdieu, 1996), where there are different and asymmetric dispositions of power occupied by certain actors; those that occupy the power core in a certain field exert power over the other actors in the same field (Bourdieu, 1996).

In the case of the OSCIPs Law, in the Nonprofit Sector field, NGOs and - mainly - traditional welfare organizations exert their power - through organizational inertia - and end up forcing the government to align its new law to their interests.

\section{REFERENCES}

Abrahamson, E. (1996, July). Management fashion. Academy of Management Review, 21(3), 21, 25485.

Alves, M. A. (2002). Terceiro Setor: o dialogismo polêmico. Unpublished doctoral dissertation, Fundação Getulio Vargas, São Paulo, Brasil.

Associação Brasileira de Captadores de Recursos - ABCR (2001). Brazilian Association of Fundraisers. Retrieved August 14, 2003, from http://www.abcr.org.br

Bava, S. C. (personal communication, October 14, 2001).

Bourdieu, P. (1996). Razões práticas sobre a teoria da ação. Campinas, SP., Brasil: Editora Papirus.

Caldas, M. \& Wood, T. (1999). Transformação e realidade organizacional: uma perspectiva brasileira. São Paulo, SP., Brasil: Editora Atlas.

Caldas, M. P. \& Vasconcelos, F. C. (2002). Cerimonial behaviour in organization intervention: the case of ISO 9000 diffusion in Brazil. Anais do Encontro Nacional dos Programas de PósGraduação em Administração. Salvador, BA, Brasil, 26.

Carvalho, C. A. P. (1999). Preservar a identidade e buscar padrões de eficiência: questões complementares ou contraditórias na atualidade das organizações não-governamentais. Anais do Encontro Nacional dos Programas de Pós-Graduação em Administração, Foz do Iguacu, PR, Brasil, 23.

Carvalho, C. A. P., Vieira, M. M. F., \& Lopes, F. D. (1999). Contribuições da perspectiva institucional para a análise das organizações. Anais do Encontro Nacional dos Programas de Pós-Graduação em Administração, Foz do Iguacu, PR, Brasil, 23.

Comunidade Solidária. 1997. $6^{\circ}$ Rodada de Interlocução Política do Conselho da Comunidade Solidária. Brasília, Brasil: Comunidade Solidaria. October 06.

DiMaggio, P. (1991). Constructing an organizational field as professional project: U.S. art museums, 1920-1940. In W. Powell, \& P. DiMaggio (Eds). The new institutionalism in organizational analysis (pp. 267-292). Chicago: Chicago University Press. 
DiMaggio, P., \& Powell, W. (1991). The iron cage revisited: institutional isomorphism and collective rationality in organizational fields. In W. Powell \& P. DiMaggio (Eds) The new institutionalism in organizational analysis:(pp. 63-81). Chicago: Chicago University Press.

Fernandes, R. C. (1994). Privado porém Público (2a ed). Rio de Janeiro, RJ., Brasil: Ed. Relume Dumará.

Ferrarezi, E. (2001). O Novo Marco Legal do Terceiro Setor no Brasil. Retrieved November 14 2003, from http://www.comunidadesolidaria.org.br

Hannan, M., \& Freeman, J. (1984, April). Structural inertia and organization change. American Sociological Review, 49(2), 49, 149-164.

Landim, L. (1993). Para além do mercado e do Estado? Filantropia e cidadania no Brasil. Rio de Janeiro, RJ., Brasil: ISER-Núcleo de Pesquisa.

Machado-da-Silva, C. (2001). Formalismo como mecanismo institucional de processos relevantes de mudança na sociedade brasileira. Anais do Encontro Nacional dos Programas de Pós-Graduação em Administração, Campinas, SP, Brasil, 25.

March, J., \& Simon, H. (1958). Organizations. New York: John Wiley and Sons.

Meyer, J. W., \& Rowan, B. (1977, September). Institutionalized organizations: formal structure as myth and ceremony. American Journal of Sociology, 83(2), 340-363.

Milofsky, C. (1997, June). Editorial: tradition. Nonprofit and Voluntary Sector Quarterly, 26(3), 109113.

Misoczky, M. C. (2001). Campo de Poder e Ação em Bourdieu: Implicações de Seu Uso em Estudos Organizacionais. Anais do Encontro Nacional dos Programas de Pós-Graduação em Administração, Campinas, SP, Brazil, 25.

Monzoni Neto, M. P. (2001). Caçadores de renda: uma investigação sobre a teoria do rent seeking. Unpublished doctoral dissertation, Fundação Getulio Vargas, São Paulo, Brasil.

Pacheco, F. L. (2001). O ambiente institucional como agente de mudança organizacional: o caso do Teatro Apolo-Hermilo. Anais do Encontro Nacional dos Programas de Pós-Graduação em Administração, Campinas, SP, Brasil, 25.

Powell, W., \& DiMaggio, P. (1991). The iron cage revisited: institutional isomorphism and collective rationality in organizational fields. In W. Powell, \& P. DiMaggio (Eds.) The new institutionalism in organizational analysis (pp. 63-81). Chicago: Chicago University Press.

Rede Brasileira de Entidades Assistenciais Filantrópicas - REBRAF (2001). Recuperado em 14 agosto, 2003, de http://www.terceirosetor.org.br

Scott, W. R., \& Meyer, J. (1991). The organization of societal sectors: propositions and early evidence. In: Powell, W. \& DiMaggio, P. (Eds.). The new institutionalism in organizational analysis (108-141). Chicago: Chicago University Press.

Selznick, P. (1949). TVA and the grassroots. Berkeley, Califórnia: University Press.

Selznick, P. (1984). Leadership in Administration: a sociological interpretation.. Berkeley, Califórnia: University Press.

Selznick, P. (1996, June). Institutionalism: “Old” and “New”. Administrative Science Quarterly, 41(2), 41, 270-277.

Spink, P. (2000). O lugar do lugar na análise organizaciona. Anais do Encontro Nacional dos Programas de Pós-Graduação em Administração, Florianópolis, SC., Brasil, 24. 
Stinchcombe, A. (1965). Social structure and organizations. In J. March (Ed). Handbook of Organizations (pp. 142-193). Chicago: Rand-McNally.

Strang, D., \& Meyer, J. (1993, August). Institutional conditions for diffusion. Theory and society, 22(4), 22, 487-511.

Tolbert, P., \& Zucker, L. (1996). The Institutionalization of Institutional Theory. In S. Clegg, C. Hardy, \& W. Nord (Eds.). Handbook of Organization Studies (pp. 175-190). London: Sage Publishers.

Tolbert, P. S., \& Zucker, L. G. (1999). A institucionalização da teoria institucional. In S. Clegg, C. Hardy, \& W. Nord (Eds.). Handbook de Estudos Organizacionais. São Paulo, Atlas.

Vieira, M. M., \& Misoczky, M. C. (2001). Instituições e poder: explorando a possibilidade de transferências conceituais. (Institutions and Power: exploring the possibility of conceptual transfers). Anais do Encontro Nacional dos Programas de Pós-Graduação em Administração, Campinas, SP, Brasil, 25.

Zucker, L. (1991). The role of institutionalization in cultural persistence. In: Powell, W., \& DiMaggio, P. (Eds.). The new institutionalism in organizational analysis (pp. 83-110). Chicago: University Chicago Press. 